\title{
Nationwide epidemiology of carbapenem resistant Klebsiella pneumoniae isolates from Greek hospitals, with regards to plazomicin and aminoglycoside resistance
}

Irene Galani ${ }^{1,3^{*}+} \mathbb{D}$, Konstantina Nafplioti ${ }^{1 \dagger}$, Panagiota Adamou ${ }^{1}$, llias Karaiskos ${ }^{2}$, Helen Giamarellou ${ }^{2}$, Maria Souli ${ }^{1}$ and Study Collaborators

\begin{abstract}
Background: To evaluate the in vitro activities of plazomicin and comparator aminoglycosides and elucidate the underlying aminoglycoside resistance mechanisms among carbapenemase-producing $K$. pneumoniae isolates collected during a nationwide surveillance study in Greek hospitals.

Methods: Three hundred single-patient carbapenemase-producing $K$. pneumoniae isolates were studied, including 200 KPC-, 50 NDM-, 21 VIM-, 14 KPC \& VIM-, 12 OXA-48-, two NDM \& OXA- and one KPC \& OXA-producing isolates. Susceptibility testing was performed by broth microdilution, and minimum inhibitory concentrations (MICs) interpreted per EUCAST breakpoints. Carbapenemase-, aminoglycoside modifying enzyme- and 16S rRNA methylase- encoding genes were detected by PCR.

Results: Of 300 isolates tested, 5.7\% were pandrug resistant and $29.3 \%$ extensively drug resistant. Plazomicin inhibited $87.0 \%$ of the isolates at $\leq 2 \mathrm{mg} / \mathrm{L}$, with $\mathrm{MIC}_{50} / \mathrm{MIC}_{90}$ of $0.5 / 4 \mathrm{mg} / \mathrm{L}$. Apramycin (a veterinary aminoglycoside) inhibited $86.7 \%$ of the isolates at $\leq 8 \mathrm{mg} / \mathrm{L}$ and was the second most active drug after plazomicin, followed by gentamicin (S, 43\%; $\left.\mathrm{MIC}_{50} / \mathrm{MIC}_{90}, 4 />256\right)$ and amikacin (S, 18.0\%; $\left.\mathrm{MIC}_{50} / \mathrm{MIC}_{90}, 32 / 128\right)$. Twenty-three (7.7\%) isolates (16 KPC-, 6 VIM- and one KPC \& OXA-48-producers) exhibited MICs $\geq 64 \mathrm{mg} / \mathrm{L}$ for plazomicin, and harbored $r m t B$ $(n=22)$ or armA $(n=1)$. AAC (6')-lb was the most common aminoglycoside modifying enzyme $(84.7 \%)$, followed by AAC(3')-Ila (25.3\%), while those two enzymes were co-produced by $21.4 \%$ of the isolates.

Conclusions: Plazomicin retains activity against most carbapenemase-producing K. pneumoniae isolated from Greek hospitals, with MICs consistently lower than those of the other aminoglycosides, even in the presence of aminoglycoside modifying enzymes. Dissemination of 16S- rRNA methylases in 8\% of the isolates is an unwelcome event that needs strict infection control measures and rigorous stewardship interventions.
\end{abstract}

Keywords: Plazomicin, K. pneumoniae, Carbapenemase, Greece

\footnotetext{
* Correspondence: egalani@med.uoa.gr

${ }^{+}$Irene Galani and Konstantina Nafplioti contributed equally to this work.

'Infectious Diseases Laboratory, 4th Department of Internal Medicine,

National and Kapodistrian University of Athens, Faculty of Medicine, Athens,

Greece

${ }^{3}$ University General Hospital "ATTIKON", Rimini 1, 12462 Chaidari, Greece

Full list of author information is available at the end of the article
}

(c) The Author(s). 2019 Open Access This article is distributed under the terms of the Creative Commons Attribution 4.0 International License (http://creativecommons.org/licenses/by/4.0/), which permits unrestricted use, distribution, and reproduction in any medium, provided you give appropriate credit to the original author(s) and the source, provide a link to the Creative Commons license, and indicate if changes were made. The Creative Commons Public Domain Dedication waiver (http://creativecommons.org/publicdomain/zero/1.0/) applies to the data made available in this article, unless otherwise stated. 


\section{Background}

Hospital infections caused by carbapenem-resistant Klebsiella pneumoniae constitute a worldwide problem associated with high morbidity, mortality, and prolongation of hospitalization and associated costs [1]. The spread of carbapenemases in K. pneumoniae has created therapeutic dilemmas for clinicians as those isolates often demonstrate resistance to many other classes of antibiotics, thus limiting our therapeutic options. Furthermore, few new antibiotics are in line to replace carbapenems [2].

In Greece, carbapenem-resistance in $K$. pneumoniae emerged in 2002 due to carbapenemase production (initially VIM and later KPC, NDM and OXA-48-like) and has become endemic [3]. The current epidemiology of carbapenemase-producing K. pneumoniae in Europe has been reported by Grundmann et al., as part of the European Survey on carbapenemase - producing Enterobacteriaceae (EuSCAPE) conducted from November 2013 till April 2014 in 35 European countries [4]. According to this survey, an average of 1.3 patients per 10,000 hospital admissions in Europe had a carbapenemaseproducing $K$. pneumoniae or E. coli infection, while this incidence specifically in Greece was 5.78, the second highest behind Italy (5.96) [4]. In this survey, among 86 carbapenem-non-susceptible $K$. pneumoniae isolates from Greece, a large proportion -were KPC-positive (65\%), followed by NDM (14\%), VIM (11\%) and OXA-48-positive (2\%) [4]. In a recent multi-center study published by our group, among 394 carbapenem-resistant $K$. pneumoniae isolates from 15 Greek hospitals $66.5 \%$ were KPC-, 13.7\% were NDM-, 8.6\% were VIM-, 5.6\% were KPC and VIMand $3.6 \%$ were OXA-48-producers [5].

Aminoglycosides are broad-spectrum antibiotics which have been used for the treatment of life-threatening infections. Many mechanisms of acquired resistance to aminoglycosides have emerged, with the aminoglycoside-modifying enzymes (AMEs) being the most prevalent. These enzymes include $\mathrm{N}$-acetyltransferases, O-nucleotidyltransferases and O-phosphotransferases, which inactivate aminoglycosides by covalently modifying specific amino or hydroxyl moieties on the drugs [6]. Another less common mechanism of resistance is the up-regulation of efflux pumps and reduction in membrane permeability developed by bacteria to affect the transport of hydrophilic aminoglycosides across cell membranes. Additionally, 16S rRNA methyltransferases (RMTs), which occur at a low incidence in clinical isolates, modify bacterial $16 \mathrm{~S}$ rRNA, the molecular target of aminoglycosides and confer high-level resistance to all widely used aminoglycosides [7].

Plazomicin is a next-generation aminoglycoside that was developed to overcome common aminoglycoside-resistance mechanisms for the treatment of patients with serious infections caused by multidrug-resistant Enterobacteriaceae, including ESBL producing and carbapenem-resistant Enterobacteriaceae [8]. Plazomicin is a semi-synthetic derivative of sisomicin, not affected by any known aminoglycoside-modifying enzymes (AMEs), except $\mathrm{N}$-acetyltransferases (AACs) AAC(2')-Ia, -Ib and -Ic (found only in Providencia spp.) [8]. Like sisomicin, it lacks the $3^{\prime}$ - and $4^{\prime}-\mathrm{OH}$ groups, thus is protected from the O-phosphotransferase (APH) APH (3') and O adenyltransferase (ANT) ANT (4') enzymes that generate resistance to amikacin. The hydroxy-aminobutyric acid substitute introduced at the N1 position of sisomicin provides protection from the $\operatorname{AAC}(3), \operatorname{ANT}\left(2^{\prime \prime}\right)$ and $\operatorname{APH}\left(2^{\prime \prime}\right)$ AMEs, while the hydroxyethyl substitute at the $6^{\prime}$ position blocks the multitude of AAC $\left(6^{\prime}\right)$ AMEs, without reducing potency, as occurred in previous efforts to shield this position [8]. Plazomicin (ZEMDRI ${ }^{\mathrm{mm}}$ ) was approved in June 2018 by the U.S. Food and Drug Administration, for adults with complicated urinary tract infections (cUTI), including pyelonephritis, caused by certain Enterobacteriaceae in patients who have limited or no alternative treatment options. ZEMDRI is an intravenous infusion, administered once daily.

In this study, we evaluated the in vitro activities of plazomicin and comparator aminoglycosides (amikacin, gentamicin and tobramycin) and elucidated the underlying aminoglycoside resistance mechanisms among 300 carbapenemase-producing $K$. pneumoniae isolates collected during a nationwide surveillance study in Greek hospitals.

\section{Methods}

\section{Clinical isolates}

A total of 300 single-patient carbapenem-non-susceptible K. pneumoniae isolates, collected between November 2014 and April 2016, from 14 Greek hospitals in six cities, were included. The isolates were collected prior to this study, during a prospective Greek multicenter study, organized by the Hellenic Society of Chemotherapy, and were archived and anonymised.

The mechanisms of carbapenem resistance in these isolates, described in a previous study [5], were production of $\mathrm{KPC}(n=200 ; 66.7 \%), \mathrm{NDM}(n=50 ; 16.7 \%)$, OXA-48 $(n=13 ; 4.3 \%)$, VIM ( $n=21 ; 7.0 \%)$, KPC \& VIM $(n=13 ; 4.3 \%), \mathrm{KPC} \&$ OXA $(n=1 ; 0.3 \%)$ and NDM \& OXA $(n=2 ; 0.7 \%)$.

Isolates were obtained from specimens of lower respiratory tract $(n=51)$, pus $(n=40), \operatorname{CSF}(n=2)$, blood $(n=55)$, urine $(n=124)$ and other sites $(n=28)$. All strains were stored at $-80^{\circ} \mathrm{C}$ and were sub-cultured twice before testing.

\section{Antimicrobial susceptibility testing}

Confirmation of the species and MIC determination of ampicillin/sulbactam, piperacillin/tazobactam, cefoxitin, 
ceftazidime, ceftriaxone, cefepime, aztreonam, imipenem, meropenen, amikacin, gentamicin, ciprofloxacin, levofloxacin, tigecycline, fosfomycin and trimethoprim/ sulfamethoxazole was performed by $V^{2}{ }^{\odot} 2$ (bioMérieux, Marcy-l'Etoile, France). Additionally, the MICs of meropenem, tigecycline, and fosfomycin were determined by Etest ${ }^{\circ}$ (AB Biodisk, Solna, Sweden) according to manufacturer's instructions and the MIC of colistin was determined by the broth microdilution method according to the Clinical and Laboratory Standards Institute (CLSI) guidelines [9].

Susceptibility testing of plazomicin (Achaogen Inc., South San Francisco, CA, USA), amikacin (DiscoveryFine Chemicals, Wimborne, UK), gentamicin (Applichem, GmbH, Darmstadt, Germany), tobramycin (Serva Electrophoresis $\mathrm{GmbH}$, Heidelberg, Germany), netilmicin (Sigma-Aldrich, St. Louis, MO), neomycin (Applichem) and apramycin (Sigma-Aldrich), was performed by the broth microdilution method according to the Clinical and Laboratory Standards Institute (CLSI) guidelines [9]. Escherichia coli ATCC 25922 and Pseudomonas aeruginosa ATCC27853 were used as quality control (QC) strains. Results were considered valid if both QC strains tested in each experiment fell within the CLSI designated QC MIC ranges for amikacin, gentamicin, tobramycin and netilmicin [10], and the NCCLS QC MIC ranges for apramycin [11]. Antimicrobial susceptibility results were interpreted according to the EUCAST recommendations (EUCAST 2018, version 8) [12]. For plazomicin the recently approved by the US Food and Drug Administration (FDA) breakpoints (S; $\leq 2 \mathrm{mg} / \mathrm{L}$, R; $\geq 8 \mathrm{mg} / \mathrm{L}$ ) were applied (https://www.fda.gov/Drugs/Deve lopmentApprovalProcess/DevelopmentResources/ucm61 1779.htm). Susceptibility breakpoints for neomycin are not established by EUCAST or CLSI, while apramycin categorical breakpoints $(S ; \leq 8 \mathrm{mg} / \mathrm{L}, \mathrm{R} ; \geq 64 \mathrm{mg} / \mathrm{L}$ ) were based on the National Antibiotic Resistance Monitoring Study (NARMS) report (National Antibiotic Resistance Monitoring System (NARMS) Working Group, 2001).

\section{Molecular characterization of aminoglycoside resistance mechanisms}

All isolates demonstrating non-susceptibility to at least one of the tested aminoglycosides were screened for the presence of AME genes, while isolates demonstrating simultaneously high-level resistance $(\geq 128 \mathrm{mg} / \mathrm{L})$ to amikacin, gentamicin, netilmicin and tobramycin, were further tested for RMT-encoding genes by PCR. Template DNA was extracted from bacteria grew in Luria Bertani broth for $18 \mathrm{~h}$ by the use of NucleoSpin Tissue kit (Machery-Nagel GmbH, Duren, Germany). Screening for AME genes $a a c\left(6^{\prime}\right)-I b$, aac(3')-IIa, aac(3')-Ia, $\operatorname{aac}\left(3^{\prime}\right)-I V$, aph(3')-VI, ant(2')-Ia and ant(3')-I, was performed by simplex 'in-house' PCR assays and for
RMT coding genes armA, rmtA, rmtB, rmtC, rmtD/ $r m t D 2, r m t E$, rmtF, rmtG, rmtH and $n p m A$, by two multiplex PCR protocols with specific primers and conditions (see Additional file 1: Table S1).

\section{Typing}

Genetic relatedness among carbapenemase producing $K$. pneumoniae isolates was evaluated by pulsed-field gel electrophoresis (PFGE) analysis of chromosomal restriction fragments obtained following cleavage with SpeI (New England BioLabs Inc., GmbH Frankfurt am Main, Germany). A dendrogram was generated from the homology matrix with a coefficient of $1.5 \%$ using the unweighted pair-group method using arithmetic averages ("UPGMA") to describe the relationships among PFGE profiles. Isolates were considered to belong to the same PFGE group if their Dice similarity index was $\geq 80 \%$.

\section{Results}

Of 300 isolates tested, 17 were pandrug-resistant (PDR) (5.7\%), 88 were extensively drug-resistant (XDR) (29.3\%) and the remaining 195 were multi-drug resistant (MDR) (65.0\%), according to the definitions provided by the ECDC [13]. Isolates were highly resistant not only to carbapenems $\left(\mathrm{MIC}_{90}>8 \mathrm{mg} / \mathrm{L}\right)$ and piperacillin-tazobactam $\left(\mathrm{MIC}_{90}>\right.$ $64 / 4 \mathrm{mg} / \mathrm{L})$ but also to ciprofloxacin $\left(\mathrm{MIC}_{90}>2 \mathrm{mg} / \mathrm{L}\right)$. Aztreonam was active against 29 isolates $(9.7 \%)$, all producing an MBL carbapenemase (VIM or NDM) and trimethoprim/sulfamethoxazole against 71 isolates (23.7\%). Colistin was the most active drug in vitro, with $66.7 \%$ of the isolates being susceptible $\left(\mathrm{MIC}_{50} / \mathrm{MIC}_{90}, 1 / 32 \mathrm{mg} / \mathrm{L}\right)$, followed by fosfomycin (S, 62.7\%, $\mathrm{MIC}_{50} / \mathrm{MIC}_{90}, 32 / 256 \mathrm{mg} / \mathrm{L}$ ). Finally, tigecycline demonstrated $53.0 \%$ susceptibility with an $\mathrm{MIC}_{50}$ of 1 and an $\mathrm{MIC}_{90}$ of $4 \mathrm{mg} / \mathrm{L}$.

Only twenty-four K. pneumoniae isolates (8.0\%) were aminoglycoside-susceptible, whereas the remaining 276 isolates $(92.0 \%)$ were resistant to at least one of the indicated aminoglycosides tested, i.e. amikacin, gentamicin, tobramycin or netilmicin, using the clinical and epidemiological breakpoints defined by EUCAST. Gentamicin was the most active in vitro aminoglycoside in clinical use, with $43.0 \%$ being susceptible, followed by amikacin (S, 18.0\%). The highest resistance rates were observed for tobramycin, with 89 and $83.3 \%$ resistant according to EUCAST and CLSI breakpoints, and netilmicin, with 87.3 and $84.3 \%$ respectively. Finally, 154 $(51.3 \%)$ and $80(26.7 \%)$ isolates were non-susceptible and resistant, respectively, to the four clinically available aminoglycosides (amikacin, gentamicin, tobramycin and netilmicin) per EUCAST breakpoints. 79 (26.3\%) and 43 (14.3\%) were non-susceptible and resistant, respectively, when CLSI breakpoints were applied. The in vitro activity of tested aminoglycosides against the studied collection of 300 clinical isolates is presented in Table 1. 
Table 1 In vitro activity of 7 aminoglycosides against 300 carbapenem-non susceptible $K$. pneumoniae in regards to carbapenemase production

\begin{tabular}{|c|c|c|c|c|c|c|c|}
\hline \multirow{2}{*}{$\begin{array}{l}\text { Antimicrobial } \\
\text { agent }\end{array}$} & \multicolumn{3}{|l|}{$\mathrm{MIC}(\mathrm{mg} / \mathrm{L})$} & \multicolumn{2}{|c|}{ Clinical breakpoint (mg/L) } & \multicolumn{2}{|c|}{ \% Susceptible } \\
\hline & Range & $\mathrm{MIC}_{50}$ & $\mathrm{MIC}_{90}$ & EUCAST & CLSI & EUCAST & CLSI \\
\hline \multicolumn{8}{|l|}{ All $(n=300)$} \\
\hline Plazomicin & $0.125->256$ & 0.5 & 4 & N/A & N/A & $87.00 \%^{a}$ & \\
\hline Amikacin & $1->256$ & 32 & 128 & $\leq 8$ & $\leq 16$ & $18.00 \%$ & $31.33 \%$ \\
\hline Gentamicin & $0.25->256$ & 4 & $>256$ & $\leq 2$ & $\leq 4$ & $43.00 \%$ & $61.33 \%$ \\
\hline Tobramycin & $0.25->256$ & 32 & 256 & $\leq 2$ & $\leq 4$ & $8.67 \%$ & $11.00 \%$ \\
\hline Netilmicin & $0.25->256$ & 128 & $>256$ & $\leq 2$ & $\leq 8$ & $9.00 \%$ & $13.00 \%$ \\
\hline Neomycin & $0.25->256$ & 16 & $>256$ & $\leq 8^{b}$ & N/A & $43.67 \%^{\mathrm{a}}$ & $\mathrm{N} / \mathrm{A}$ \\
\hline Apramycin & $1-128$ & 8 & 16 & $\leq 8^{c}$ & N/A & $86.67 \%^{c}$ & \\
\hline \multicolumn{8}{|l|}{$\operatorname{KPC}(n=201)^{d}$} \\
\hline Plazomicin & $0.125->256$ & 1 & 4 & N/A & N/A & $84.58 \%{ }^{a}$ & \\
\hline Amikacin & $1->256$ & 32 & 128 & $\leq 8$ & $\leq 16$ & $17.91 \%$ & $31.34 \%$ \\
\hline Gentamicin & $0.25->256$ & 4 & 64 & $\leq 2$ & $\leq 4$ & $48.76 \%$ & $71.14 \%$ \\
\hline Tobramycin & $0.25->256$ & 32 & 256 & $\leq 2$ & $\leq 4$ & $11.94 \%$ & $14.93 \%$ \\
\hline Netilmicin & $0.25->256$ & 128 & $>256$ & $\leq 2$ & $\leq 8$ & $11.94 \%$ & $16.92 \%$ \\
\hline Neomycin & $0.5->256$ & 32 & $>256$ & $\leq 8^{\mathrm{b}}$ & N/A & $31.34 \%^{b}$ & N/A \\
\hline Apramycin & $1-128$ & 4 & 16 & $\leq 8^{c}$ & N/A & $86.57 \%^{c}$ & \\
\hline \multicolumn{8}{|l|}{$\operatorname{NDM}(n=52)^{\mathrm{e}}$} \\
\hline Plazomicin & $0.125-2$ & 0.5 & 1 & N/A & N/A & $100.00 \%^{a}$ & \\
\hline Amikacin & $8-256$ & 32 & 64 & $\leq 8$ & $\leq 16$ & $17.31 \%$ & $44.23 \%$ \\
\hline Gentamicin & $1->256$ & 64 & $>256$ & $\leq 2$ & $\leq 4$ & $28.85 \%$ & $36.54 \%$ \\
\hline Tobramycin & $16->256$ & 32 & 128 & $\leq 2$ & $\leq 4$ & $0.00 \%$ & $0.00 \%$ \\
\hline Netilmicin & $8->256$ & 128 & $>256$ & $\leq 2$ & $\leq 8$ & $0.00 \%$ & $1.92 \%$ \\
\hline Neomycin & $1-32$ & 2 & 8 & $\leq 8^{b}$ & N/A & $94.23 \%{ }^{b}$ & N/A \\
\hline Apramycin & $2-32$ & 4 & 8 & $\leq 8^{c}$ & N/A & $94.23 \%^{c}$ & \\
\hline \multicolumn{8}{|l|}{$\operatorname{VIM}(n=21)$} \\
\hline Plazomicin & $0.125->256$ & 1 & $>256$ & N/A & N/A & $71.43 \%^{a}$ & \\
\hline Amikacin & $1->256$ & 32 & $>256$ & $\leq 8$ & $\leq 16$ & $19.05 \%$ & $42.86 \%$ \\
\hline Gentamicin & $1->256$ & 128 & $>256$ & $\leq 2$ & $\leq 4$ & $38.10 \%$ & $42.86 \%$ \\
\hline Tobramycin & $4->256$ & 32 & $>256$ & $\leq 2$ & $\leq 4$ & $0.00 \%$ & $4.76 \%$ \\
\hline Netilmicin & $0.25->256$ & 64 & $>256$ & $\leq 2$ & $\leq 8$ & $0.00 \%$ & $0.00 \%$ \\
\hline Neomycin & $0.5->256$ & 32 & $>256$ & $\leq 8^{b}$ & N/A & $33.33 \%^{b}$ & N/A \\
\hline Apramycin & $2-64$ & 4 & 16 & $\leq 8^{c}$ & N/A & $80.95 \%^{c}$ & \\
\hline \multicolumn{8}{|l|}{ OXA-48 $(n=12)$} \\
\hline Plazomicin & $0.125-4$ & 0.5 & 2 & N/A & N/A & $91.67 \%^{a}$ & \\
\hline Amikacin & $2-64$ & 16 & 32 & $\leq 8$ & $\leq 16$ & $33.33 \%$ & $58.33 \%$ \\
\hline Gentamicin & $1-256$ & 128 & 256 & $\leq 2$ & $\leq 4$ & $16.67 \%$ & $16.67 \%$ \\
\hline Tobramycin & $0.5-64$ & 64 & 64 & $\leq 2$ & $\leq 4$ & $16.67 \%$ & $16.67 \%$ \\
\hline Netilmicin & $0.5-256$ & 128 & 256 & $\leq 2$ & $\leq 8$ & $16.67 \%$ & $16.67 \%$ \\
\hline Neomycin & $0.25-256$ & 2 & 16 & $\leq 8^{b}$ & N/A & $83.33 \%^{b}$ & N/A \\
\hline Apramycin & $4-8$ & 8 & 8 & $\leq 8^{c}$ & N/A & $100.00 \%^{c}$ & \\
\hline \multicolumn{8}{|c|}{ KPC and VIM $(n=14)$} \\
\hline Plazomicin & $0.25-2$ & 1 & 2 & N/A & N/A & $92.86 \%^{a}$ & \\
\hline
\end{tabular}


Table 1 In vitro activity of 7 aminoglycosides against 300 carbapenem-non susceptible K. pneumoniae in regards to carbapenemase production (Continued)

\begin{tabular}{|c|c|c|c|c|c|c|c|}
\hline \multirow{2}{*}{$\begin{array}{l}\text { Antimicrobial } \\
\text { agent }\end{array}$} & \multicolumn{3}{|l|}{ MIC (mg/L) } & \multicolumn{2}{|c|}{ Clinical breakpoint (mg/L) } & \multicolumn{2}{|c|}{$\%$ Susceptible } \\
\hline & Range & $\mathrm{MIC}_{50}$ & $\mathrm{MIC}_{90}$ & EUCAST & CLSI & EUCAST & CLSI \\
\hline Amikacin & $4->256$ & 64 & 256 & $\leq 8$ & $\leq 16$ & $7.14 \%$ & $28.57 \%$ \\
\hline Gentamicin & $1-64$ & 4 & 8 & $\leq 2$ & $\leq 4$ & $42.86 \%$ & $78.57 \%$ \\
\hline Tobramycin & $8->256$ & 32 & 128 & $\leq 2$ & $\leq 4$ & $0.00 \%$ & $0.00 \%$ \\
\hline Netilmicin & $4->256$ & 128 & $>256$ & $\leq 2$ & $\leq 8$ & $0.00 \%$ & $7.14 \%$ \\
\hline Neomycin & $0.5->256$ & $>256$ & $>256$ & $\leq 8^{b}$ & N/A & $14.29 \%^{b}$ & N/A \\
\hline Apramycin & $2-32$ & 8 & 32 & $\leq 8^{c}$ & N/A & $57.14 \%^{c}$ & \\
\hline
\end{tabular}

$\mathrm{N} / \mathrm{A}$, not available (breakpoints have not been established)

${ }^{a}$ For plazomicin, the breakpoint recently approved by the FDA was used

${ }^{\mathrm{b}}$ For neomycin, EUCAST epidemiological cut-off values (ECOFFs) for E.coli were used

c For apramycin, epidemiological breakpoints from the European Food Safety Authority (EFSA) were used

d One isolate co-producing KPC and OXA-48-like is included

e Two isolates co-producing NDM and OXA-48-like are included

Plazomicin MICs ranged from 0.125 to $>256 \mathrm{mg} / \mathrm{L}$, with $\mathrm{MIC}_{50}$ and $\mathrm{MIC}_{90}$ of 0.5 and $4 \mathrm{mg} / \mathrm{L}$, respectively. Of note, $87.0 \%$ of the isolates were inhibited by plazomicin at $\leq 2 \mathrm{mg} / \mathrm{L}$, which is the breakpoint approved by the FDA, and $91.3 \%$ at $\leq 4 \mathrm{mg} / \mathrm{L}$. Plazomicin was the most active aminoglycoside tested with an $\mathrm{MIC}_{90}$ value $\geq 32$ times lower than that of all aminoglycosides in clinical use tested, $>64$ times lower than neomycin and 4 times lower than apramycin (Table 1). Among isolates that were non-susceptible or resistant to the four aminoglycosides in clinical use (according to the EUCAST breakpoints), plazomicin exhibited an $\mathrm{MIC}_{50}$ of 1 and $2 \mathrm{mg} / \mathrm{L}$, respectively. The activities of the aminoglycosides against all isolates as well as isolates categorized according to the specific carbapenemase produced are summarized in Table 1. Further, the plazomicin MIC distribution and the cumulative percentage inhibited, in relation to the carbapenemase produced and in relation to amikacin and/or gentamicin susceptibility are presented in Tables 2 and 3, respectively.

Twenty-three strains (7.7\%), isolated in seven of the 14 hospitals, were highly resistant to all indicated aminoglycosides (MICs $\geq 256 \mathrm{mg} / \mathrm{L}$ ), had highly elevated plazomicin MICs $(\geq 64 \mathrm{mg} / \mathrm{L})$ and harbored a RMT gene (Tables 4 and 5). Fifteen KPC-, 6 VIM- and one KPC \& OXA-48 -producing $K$. pneumoniae isolates harbored $r m t B$, and one KPC-producing K. pneumoniae isolate harbored $\operatorname{armA}$. It is of note that none of the NDMproducing $K$. pneumoniae isolates produced a RMT although $b l a_{\mathrm{NDM}^{-}}$-carrying plasmids frequently are associated with $\operatorname{armA}, r m t B, r m t C$, and $r m t F$ [7].

For strains carrying no RMT gene $(n=277)$, the $\mathrm{MIC}_{90}$ of plazomicin was $2 \mathrm{mg} / \mathrm{L}$, with $94.2 \%$ of isolates being susceptible and the highest MIC observed at $8 \mathrm{mg} / \mathrm{L}$.

Among those 277 isolates, 148 (53.4\%) and 225 $(80.5 \%)$ were non-susceptible to gentamicin and amikacin, respectively. One hundred thirty-one (47.3\%) isolates were non-susceptible to both gentamicin and amikacin and against 120 (91.6\%) of these, the MIC of plazomicin was $\leq 2 \mathrm{mg} / \mathrm{L}$ (Table 3 ). Isolates with plazomicin MIC $8 \mathrm{mg} / \mathrm{L}(n=3)$ were non-susceptible to all other aminoglycosides tested including apramycin.

The most common AME gene was aac (6') -Ib (254 strains; 84.7\%), followed by aph(3')-Ia (167 strains; 55.7\%), ant( $\left.3^{\prime}\right)$-Ia (156 strains; 52.0\%), and aac(3')-IIa (76 strains; $25.3 \%)$. Nine isolates harboured aph( $\left.3^{\prime}\right)$-VIa (3.0\%) and three isolates ant(2')-Ia (1.0\%), while all isolates were negative for $a a c(3)-I a$ and $a a c(3)-I V a$ (Table 4).

The majority of isolates harbored at least two (83 isolates; $27.7 \%$ ) or more AME genes (146 isolates; 48.7\%), while less commonly observed were isolates with one AME gene (50 isolates; $16.7 \%$ or no AME gene (21 isolates; $7 \%$ ) (Fig. 1b). The combination of aac(6')-Ib, ant( (3')-I and aph(3')-Ia was the most common (86 isolates; $28.7 \%$ ), followed by $a a c\left(6^{\prime}\right)-I b$ alone (42 isolates; $14.0 \%$ ) and $a a c\left(6^{\prime}\right)-I b$ with aac(3')-IIa (32 isolates; $10.7 \%$ ) (Table 4). In addition, 23 of the isolates that harboured one or more AME gene also harboured an RMT gene.

Associations of AMEs, and AME combinations, with aminoglycoside MICs are shown in Table 5. Additionally all isolates non-susceptible to neomycin $(n=169)$ harboured the $\operatorname{aph}\left(3^{\prime}\right)-I(n=167)$ or/and the $\operatorname{aph}\left(3^{\prime}\right)-V I$ $(n=5)$ gene. Among the 246 amikacin non-susceptible isolates, $214(87.0 \%)$ encoded the $a a c\left(6^{\prime}\right)-I b$ gene, nine encoded the $a a c\left(6^{\prime}\right)-I b$ and the $a p h\left(3^{\prime}\right)-V I$, and 23 encoded the $r m t B$ or the $\operatorname{arm} A$ genes $\left( \pm a a c\left(6^{\prime}\right)-I b\right)$. Among the 171 gentamicin non-susceptible isolates, 61 (35.7\%) encoded the $\operatorname{aac}\left(3^{\prime}\right)$-IIa gene, two encoded the ant $\left(2^{\prime}\right)$-Ia gene and 23 encoded the $r m t B\left( \pm a a c\left(3^{\prime}\right)-I I a\right)$ or the $\operatorname{arm} A$. Twenty of the 254 isolates that harboured the $a a c\left(6^{\prime}\right)-I b$ gene and 12 of the 76 isolates that harboured the aac(3')-IIa did not express phenotypic resistance to amikacin (MIC $2-8 \mathrm{mg} / \mathrm{L}$ ) or gentamicin 
Table 2 MIC and cumulative percent inhibited distributions for plazomicin, in relation to the carbapenemase type produced by the 300 K. pneumoniae isolates

\begin{tabular}{|c|c|c|c|c|c|c|c|c|c|c|c|}
\hline \multirow[t]{2}{*}{ Carbapenemase } & \multirow{2}{*}{$\begin{array}{l}\text { No of } \\
\text { isolates }\end{array}$} & \multicolumn{10}{|c|}{ No of isolates / (cumulative \% of isolates) inhibited at plazomicin MIC (mg/L) of a } \\
\hline & & $\leq 0.125$ & 0.25 & 0.5 & 1 & 2 & 4 & 8 & 16 & 32 & $\geq 64^{b}$ \\
\hline KPC & 200 & $\begin{array}{l}3 \\
(1.5)\end{array}$ & $\begin{array}{l}46 \\
(24.5)\end{array}$ & $\begin{array}{l}46 \\
(47.5)\end{array}$ & $\begin{array}{l}57 \\
(76.0)\end{array}$ & $\begin{array}{l}18 \\
(85.0)\end{array}$ & $\begin{array}{l}11 \\
(90.5)\end{array}$ & $\begin{array}{l}3 \\
(92.0)\end{array}$ & $\begin{array}{l}0 \\
(92.0)\end{array}$ & $\begin{array}{l}0 \\
(92.0)\end{array}$ & $\begin{array}{l}16 \\
(100)\end{array}$ \\
\hline NDM & 50 & $\begin{array}{l}1 \\
(2.0)\end{array}$ & $\begin{array}{l}23 \\
(48.0)\end{array}$ & $\begin{array}{l}13 \\
(74.0)\end{array}$ & $\begin{array}{l}11 \\
(96.0)\end{array}$ & $\begin{array}{l}2 \\
(100)\end{array}$ & $\begin{array}{l}0 \\
(-)\end{array}$ & $\begin{array}{l}0 \\
(-)\end{array}$ & $\begin{array}{l}0 \\
(-)\end{array}$ & $\begin{array}{l}0 \\
(-)\end{array}$ & $\begin{array}{l}0 \\
(-)\end{array}$ \\
\hline VIM & 21 & $\begin{array}{l}3 \\
(14.3)\end{array}$ & $\begin{array}{l}3 \\
(28.6)\end{array}$ & $\begin{array}{l}3 \\
(42.9)\end{array}$ & $\begin{array}{l}5 \\
(66.7)\end{array}$ & $\begin{array}{l}1 \\
(71.4)\end{array}$ & $\begin{array}{l}0 \\
(71.4)\end{array}$ & $\begin{array}{l}0 \\
(71.4)\end{array}$ & $\begin{array}{l}0 \\
(71.4)\end{array}$ & $\begin{array}{l}0 \\
(71.4)\end{array}$ & $\begin{array}{l}6 \\
(100)\end{array}$ \\
\hline OXA-48 & 12 & $\begin{array}{l}1 \\
(8.3)\end{array}$ & $\begin{array}{l}2 \\
(25.0)\end{array}$ & $\begin{array}{l}5 \\
(66.7)\end{array}$ & $\begin{array}{l}2 \\
(83.3)\end{array}$ & $\begin{array}{l}1 \\
(91.7)\end{array}$ & $\begin{array}{l}1 \\
(100)\end{array}$ & $\begin{array}{l}0 \\
(-)\end{array}$ & $\begin{array}{l}0 \\
(-)\end{array}$ & $\begin{array}{l}0 \\
(-)\end{array}$ & $\begin{array}{l}0 \\
(-)\end{array}$ \\
\hline $\mathrm{KPC}+\mathrm{VIM}$ & 14 & $\begin{array}{l}0 \\
(0.0)\end{array}$ & $\begin{array}{l}2 \\
(14.3)\end{array}$ & $\begin{array}{l}0 \\
(14.3)\end{array}$ & $\begin{array}{l}8 \\
(71.4)\end{array}$ & $\begin{array}{l}3 \\
(92.9)\end{array}$ & $\begin{array}{l}1 \\
(100)\end{array}$ & $\begin{array}{l}0 \\
(-)\end{array}$ & $\begin{array}{l}0 \\
(-)\end{array}$ & $\begin{array}{l}0 \\
(-)\end{array}$ & $\begin{array}{l}0 \\
(-)\end{array}$ \\
\hline $\mathrm{NDM}+\mathrm{OXA}-48$ & 2 & $\begin{array}{l}0 \\
(0.0)\end{array}$ & $\begin{array}{l}2 \\
(100)\end{array}$ & $\begin{array}{l}0 \\
(-)\end{array}$ & $\begin{array}{l}0 \\
(-)\end{array}$ & $\begin{array}{l}0 \\
(-)\end{array}$ & $\begin{array}{l}0 \\
(-)\end{array}$ & $\begin{array}{l}0 \\
(-)\end{array}$ & $\begin{array}{l}0 \\
(-)\end{array}$ & $\begin{array}{l}0 \\
(-)\end{array}$ & $\begin{array}{l}0 \\
(-)\end{array}$ \\
\hline $\mathrm{KPC}+\mathrm{OXA}-48$ & 1 & $\begin{array}{l}0 \\
(0.0)\end{array}$ & $\begin{array}{l}0 \\
(0.0)\end{array}$ & $\begin{array}{l}0 \\
(0.0)\end{array}$ & $\begin{array}{l}0 \\
(0.0)\end{array}$ & $\begin{array}{l}0 \\
(0.0)\end{array}$ & $\begin{array}{l}0 \\
(0.0)\end{array}$ & $\begin{array}{l}0 \\
(0.0)\end{array}$ & $\begin{array}{l}0 \\
(0.0)\end{array}$ & $\begin{array}{l}0 \\
(0.0)\end{array}$ & $\begin{array}{l}1 \\
(100)\end{array}$ \\
\hline All & 300 & $\begin{array}{l}8 \\
(2.7)\end{array}$ & $\begin{array}{l}78 \\
(28.7)\end{array}$ & $\begin{array}{l}67 \\
(51.0)\end{array}$ & $\begin{array}{l}83 \\
(78.7)\end{array}$ & $\begin{array}{l}25 \\
(87.0)\end{array}$ & $\begin{array}{l}13 \\
(91.3)\end{array}$ & $\begin{array}{l}3 \\
(92.3)\end{array}$ & $\begin{array}{l}0 \\
(92.3)\end{array}$ & $\begin{array}{l}0 \\
(92.3)\end{array}$ & $\begin{array}{l}23 \\
(100)\end{array}$ \\
\hline
\end{tabular}

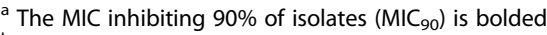

${ }^{b}$ All isolates $(n=23)$ with plazomicin MIC $\geq 64 \mathrm{mg} / \mathrm{L}$ harbored a $16 \mathrm{~S}$ rRNA methylase gene

(MIC 1-2 mg/L), although those two genes confer resistance to amikacin and gentamicin, respectively.

PFGE genotyping revealed a multiclonal population of KPC-producing K. pneumoniae, with a prevalent PFGE profile $(42.0 \%)$, consisting of nine variants, all detected in more than one center. Additionally, there were two more PFGE profiles identified, consisting of three and two variants each, and another 24 PFGE profiles that included a few isolates each.

The 21 VIM-, the $14 \mathrm{KPC}$ - and VIM- and the 12 OXA-48-like - producing $K$. pneumoniae isolates were multiclonal, with no particular clone prevailing as different clones between hospitals and within hospitals were observed.

However, PFGE genotyping of NDM-producing isolates demonstrated great genetic similarity in the 48 (96.0\%) isolates (dominant clone A), consisting of three main variants (A1 to A3), two of which were detected in more than one center. Additionally, two isolates, each with a distinct PFGE profile, were also detected (4.0\%). Moreover, two isolates carrying both $b l a_{\mathrm{NDM}}$ and $b l a_{\text {OXA-48-like }}$ belonged to dominant clone A.

The $23 \mathrm{~K}$. pneumoniae isolates that harboured an RMT (rmtB or armA) and had highly elevated plazomicin MICs, belonged to six clonal types, suggesting that these isolates were not clonal, although clonal dissemination of $r m t B$ positive VIM or KPC producing isolates was observed in three hospitals.

\section{Discussion}

Among contemporary carbapenem-resistant K. pneumoniae isolates from Greece, where KPC-producing pathogens remain predominant, followed by NDM-producing isolates, plazomicin was more potent than that of the comparator aminoglycosides gentamicin and amikacin. These results are similar to those reported in previous studies with carbapenem-resistant enterobacteriaceae from diverse geographic regions [1419].

There are several noteworthy findings in our study. We observed that in Greece, aminoglycoside resistance in carbapenemase-producing K. pneumoniae clinical isolates is predominantly caused by the production of AMEs (85.3\% of isolates), while the occurrence of RMTs was observed in $7.7 \%$. A remarkable AME diversity was observed. Overall, 23 different AME patterns (maximum of five genes/isolate) correlating with different levels of aminoglycoside resistance were identified.

The $a a c\left(6^{\prime}\right)-I b$ enzyme was the most common gene detected and found in $\geq 71.4 \%$ of carbapenemase producing strains, regardless of the carbapenemase present, whilst the $\operatorname{aac}\left(3^{\prime}\right)$-IIa gene was mainly associated with NDM- and OXA-48-producing isolates. The ant( $\left.3^{\prime}\right)-I$ gene was always associated with VIM-, while $\operatorname{aph}\left(3^{\prime}\right)-I a$ was mainly associated with KPC and VIM-producing $K$. pneumoniae.

Notably, the aminoglycoside resistance phenotype was not always a reliable predictor of the AME genotype. For instance, in $49.7 \%$ of the gentamicin non-susceptible isolates the $a a c\left(3^{\prime}\right)-I I a$, $\operatorname{ant}\left(2^{\prime}\right)-I a, \operatorname{acc}\left(3^{\prime}\right)-I a$ or $a a c(3)-I V$ genes, were not detected, while aac( $\left.3^{\prime}\right)$-IIa was detected in $4 \%$ of the gentamicin susceptible isolates (MICs 1-2 $\mathrm{mg} / \mathrm{L}$ ). All amikacin non-susceptible isolates harbored the $a a c\left(6^{\prime}\right)-I b$ or an RMT gene, while $20(6.7 \%)$ amikacin 
Table 3 MIC and cumulative percent inhibited distributions for plazomicin, in relation to gentamicin and amikacin susceptibility (according EUCAST criteria)

\begin{tabular}{|c|c|c|c|c|c|c|c|c|c|c|c|}
\hline \multirow[t]{2}{*}{ Aminoglycoside susceptibility } & \multirow{2}{*}{$\begin{array}{l}\text { No of } \\
\text { isolates }\end{array}$} & \multicolumn{10}{|c|}{ No of isolates / (cumulative \% of isolates) inhibited at plazomicin MIC (mg/L) of a } \\
\hline & & $\leq 0.125$ & 0.25 & 0.5 & 1 & 2 & 4 & 8 & 16 & 32 & $\geq 64^{d}$ \\
\hline Amikacin $\mathrm{S}^{\mathrm{b}}$ & 54 & $\begin{array}{l}5 \\
(9.3)\end{array}$ & $\begin{array}{l}23 \\
(51.9)\end{array}$ & $\begin{array}{l}11 \\
(72.2)\end{array}$ & $\begin{array}{l}9 \\
(88.9)\end{array}$ & $\begin{array}{l}1 \\
(90.7)\end{array}$ & $\begin{array}{l}5 \\
(100)\end{array}$ & $\begin{array}{l}0 \\
(-)\end{array}$ & $\begin{array}{l}0 \\
(-)\end{array}$ & $\begin{array}{l}0 \\
(-)\end{array}$ & $\begin{array}{l}0 \\
(-)\end{array}$ \\
\hline Amikacin NS ${ }^{\mathrm{C}}$ & 246 & $\begin{array}{l}3 \\
(1.2)\end{array}$ & $\begin{array}{l}55 \\
(23.6)\end{array}$ & $\begin{array}{l}56 \\
(46.3)\end{array}$ & $\begin{array}{l}74 \\
(76.4)\end{array}$ & $\begin{array}{l}24 \\
(86.2)\end{array}$ & $\begin{array}{l}8 \\
(89.4)\end{array}$ & $\begin{array}{l}3 \\
(90.7)\end{array}$ & $\begin{array}{l}0 \\
(90.7)\end{array}$ & $\begin{array}{l}0 \\
(90.7)\end{array}$ & $\begin{array}{l}23 \\
(100)\end{array}$ \\
\hline $\begin{array}{l}\text { Amikacin NS } \\
\text { (excluding RMT positive isolates) }\end{array}$ & 223 & $\begin{array}{l}3 \\
(1.3)\end{array}$ & $\begin{array}{l}55 \\
(26.0)\end{array}$ & $\begin{array}{l}56 \\
(51.1)\end{array}$ & $\begin{array}{l}74 \\
(84.3)\end{array}$ & $\begin{array}{l}24 \\
(95.1)\end{array}$ & $\begin{array}{l}8 \\
(98.7)\end{array}$ & $\begin{array}{l}3 \\
(100)\end{array}$ & $\begin{array}{l}0 \\
(-)\end{array}$ & $\begin{array}{l}0 \\
(-)\end{array}$ & $\begin{array}{l}0 \\
(-)\end{array}$ \\
\hline Gentamicin S & 129 & $\begin{array}{l}3 \\
(2.3)\end{array}$ & $\begin{array}{l}52 \\
(42.6)\end{array}$ & $\begin{array}{l}41 \\
(74.4)\end{array}$ & $\begin{array}{l}24 \\
(93.0)\end{array}$ & $\begin{array}{l}5 \\
(96.9)\end{array}$ & $\begin{array}{l}4 \\
(100)\end{array}$ & $\begin{array}{l}0 \\
(-)\end{array}$ & $\begin{array}{l}0 \\
(-)\end{array}$ & $\begin{array}{l}0 \\
(-)\end{array}$ & $\begin{array}{l}0 \\
(-)\end{array}$ \\
\hline Gentamicin NS & 171 & $\begin{array}{l}5 \\
(2.9)\end{array}$ & $\begin{array}{l}26 \\
(18.1)\end{array}$ & $\begin{array}{l}26 \\
(33.3)\end{array}$ & $\begin{array}{l}59 \\
(67.8)\end{array}$ & $\begin{array}{l}20 \\
(79.5)\end{array}$ & $\begin{array}{l}9 \\
(84.8)\end{array}$ & $\begin{array}{l}3 \\
(86.5)\end{array}$ & $\begin{array}{l}0 \\
(86.5)\end{array}$ & $\begin{array}{l}0 \\
(86.5)\end{array}$ & $\begin{array}{l}23 \\
(100)\end{array}$ \\
\hline $\begin{array}{l}\text { Gentamicin NS } \\
\text { (excluding RMT positive isolates) }\end{array}$ & 148 & $\begin{array}{l}5 \\
(3.4)\end{array}$ & $\begin{array}{l}26 \\
(20.9)\end{array}$ & $\begin{array}{l}26 \\
(38.5)\end{array}$ & $\begin{array}{l}59 \\
(78.4)\end{array}$ & $\begin{array}{l}20 \\
(91.9)\end{array}$ & $\begin{array}{l}9 \\
(97.8)\end{array}$ & $\begin{array}{l}3 \\
(100)\end{array}$ & $\begin{array}{l}0 \\
(-)\end{array}$ & $\begin{array}{l}0 \\
(-)\end{array}$ & $\begin{array}{l}0 \\
(-)\end{array}$ \\
\hline Amikacin NS/Gentamicin NS & 154 & $\begin{array}{l}2 \\
(1.3)\end{array}$ & $\begin{array}{l}15 \\
(11.0)\end{array}$ & $\begin{array}{l}25 \\
(27.3)\end{array}$ & $\begin{array}{l}58 \\
(64.9)\end{array}$ & $\begin{array}{l}20 \\
(77.9)\end{array}$ & $\begin{array}{l}8 \\
(83.1)\end{array}$ & $\begin{array}{l}3 \\
(85.1)\end{array}$ & $\begin{array}{l}0 \\
(85.1)\end{array}$ & $\begin{array}{l}0 \\
(85.1)\end{array}$ & $\begin{array}{l}23 \\
(100)\end{array}$ \\
\hline $\begin{array}{l}\text { Amikacin NS/Gentamicin NS } \\
\text { (excluding RMT positive isolates) }\end{array}$ & 131 & $\begin{array}{l}2 \\
(1.5)\end{array}$ & $\begin{array}{l}15 \\
(13.0)\end{array}$ & $\begin{array}{l}25 \\
(32.1)\end{array}$ & $\begin{array}{l}58 \\
(76.3)\end{array}$ & $\begin{array}{l}20 \\
(91.6)\end{array}$ & $\begin{array}{l}8 \\
(97.7)\end{array}$ & $\begin{array}{l}3 \\
(100)\end{array}$ & $\begin{array}{l}0 \\
(-)\end{array}$ & $\begin{array}{l}0 \\
(-)\end{array}$ & $\begin{array}{l}0 \\
(-)\end{array}$ \\
\hline Amikacin NS/Gentamicin S & 92 & $\begin{array}{l}1 \\
(1.1)\end{array}$ & $\begin{array}{l}40 \\
(44.6)\end{array}$ & $\begin{array}{l}31 \\
(78.3)\end{array}$ & $\begin{array}{l}16 \\
(95.7)\end{array}$ & $\begin{array}{l}4 \\
(100)\end{array}$ & $\begin{array}{l}0 \\
(-)\end{array}$ & $\begin{array}{l}0 \\
(-)\end{array}$ & $\begin{array}{l}0 \\
(-)\end{array}$ & $\begin{array}{l}0 \\
(-)\end{array}$ & $\begin{array}{l}0 \\
(-)\end{array}$ \\
\hline Amikacin S/Gentamicin NS & 17 & $\begin{array}{l}3 \\
(17.6)\end{array}$ & $\begin{array}{l}11 \\
(82.4)\end{array}$ & $\begin{array}{l}1 \\
(88.2)\end{array}$ & $\begin{array}{l}1 \\
(94.1)\end{array}$ & $\begin{array}{l}0 \\
(94.1)\end{array}$ & $\begin{array}{l}1 \\
(100)\end{array}$ & $\begin{array}{l}0 \\
(-)\end{array}$ & $\begin{array}{l}0 \\
(-)\end{array}$ & $\begin{array}{l}0 \\
(-)\end{array}$ & $\begin{array}{l}0 \\
(-)\end{array}$ \\
\hline Amikacin S/Gentamicin S & 28 & $\begin{array}{l}1 \\
\text { (3.6) }\end{array}$ & $\begin{array}{l}8 \\
(32.1)\end{array}$ & $\begin{array}{l}6 \\
(53.6)\end{array}$ & $\begin{array}{l}8 \\
(82.1)\end{array}$ & $\begin{array}{l}1 \\
(85.7)\end{array}$ & $\begin{array}{l}4 \\
(100)\end{array}$ & $\begin{array}{l}0 \\
(-)\end{array}$ & $\begin{array}{l}0 \\
(-)\end{array}$ & $\begin{array}{l}0 \\
(-)\end{array}$ & $\begin{array}{l}0 \\
(-)\end{array}$ \\
\hline All isolates excluding RMT positives & 277 & $\begin{array}{l}8 \\
(2.9)\end{array}$ & $\begin{array}{l}78 \\
(31.0)\end{array}$ & $\begin{array}{l}67 \\
(55.2)\end{array}$ & $\begin{array}{l}83 \\
(85.2)\end{array}$ & $\begin{array}{l}25 \\
(94.2)\end{array}$ & $\begin{array}{l}13 \\
(98.9)\end{array}$ & $\begin{array}{l}3 \\
(100)\end{array}$ & $\begin{array}{l}0 \\
(-)\end{array}$ & $\begin{array}{l}0 \\
(-)\end{array}$ & $\begin{array}{l}0 \\
(-)\end{array}$ \\
\hline
\end{tabular}

${ }^{a}$ The MIC inhibiting $90 \%$ of isolates ( $\mathrm{MIC}_{90}$ ) is bolded

b $\mathrm{S}$; susceptible

' NS; non susceptible

${ }^{\mathrm{d}}$ All isolates $(n=23)$ with plazomicin MIC $\geq 64 \mathrm{mg} / \mathrm{L}$ harbored a $16 \mathrm{~S}$ rRNA methylase gene

susceptible isolates harbored also the $a a c\left(6^{\prime}\right)-I b$ gene. This is consistent with previous studies where, despite the presence of $a a c\left(6^{\prime}\right)-I b$, low amikacin MICs $(2-8 \mathrm{mg} / \mathrm{L})$ have been reported in $K$. pneumoniae and E. coli strains $[16,20,21]$. The contribution of multiple concurrent resistance mechanisms and differentiations in catalytic activity of AME genes is probably the explanation for this. There are 45 non-identical AAC(6 $\left.6^{\prime}\right)$-Ib-related entries in the NCBI database, with 1 to 8 amino acid differences and a total of 24 positions showing amino acid variations. Among them, 32 have identical name but a non-identical amino acid sequence (97-99.5\% similarity). Some of these variants have conserved specificity, while others have not, i.e. $\mathrm{AAC}\left(6^{\prime}\right)-\mathrm{Ib}_{11}$ has an extended resistance spectrum that includes gentamicin or AAC (6')-Ib' confers resistance to gentamicin but not to amikacin [22]. On the contrary, the presence of high resistance (MIC $\geq 256 \mathrm{mg} / \mathrm{L}$ ) to both amikacin and gentamicin correctly predicted (95.5\%) the presence of an RMT gene, which also displayed similar highly elevated plazomicin MICs, which is consistent with the limitations of plazomicin and the aminoglycoside class.

There were 23 isolates that encoded both a carbapenemase and an RMT. Sixteen KPC- (8.0\%), six VIM(28.6\%) and one KPC \& OXA-48 -producing K. pneumoniae isolates harbored either $r m t B$ or armA.

Acquired aminoglycoside resistance mediated by 16S-RMTases is a relatively new mechanism described in the early 2000s. Co-association of 16S-RMTases with carbapenemases leads to XDR and, in some instances, to PDR phenotypes [7].

In previous literature reports, plazomicin MICs were predominantly $\leq 4 \mathrm{mg} / \mathrm{L}$, except for CRE isolates that produced the NDM-1 metallo- $\beta$-lactamase [15]. Interestingly, our findings showed that all 52 NDM-producing K. pneumoniae had plazomicin MICs $\leq 2 \mathrm{mg} / \mathrm{L}$. This was similar to results found against NDM-producing Enterobacteriaceae from Brazil, which exhibited plazomicin MICs $\leq 4 \mathrm{mg} / \mathrm{L}$ [19]. In both countries, bla $_{\mathrm{NDM}}$ gene has been reported to be located on an IncFII-type plasmid [23-26], while aminoglycoside susceptibility was variable, suggesting that the mechanism of resistance was 
Table 4 Presence of aminoglycoside-modifying enzyme gene combination in relation to carbapenemase gene content

\begin{tabular}{|c|c|c|c|c|c|c|c|c|}
\hline AME gene(s) & $\begin{array}{l}\text { Carbapenemase gene } \\
\text { No (\%) of isolates }\end{array}$ & $\begin{array}{l}b l a_{\mathrm{KPC}} \\
(n=200)\end{array}$ & $\begin{array}{l}\text { bla } a_{\mathrm{NDM}} \\
(n=50)\end{array}$ & $\begin{array}{l}\text { bla } a_{\mathrm{VIM}} \\
(n=21)\end{array}$ & $\begin{array}{l}b a_{\mathrm{OXA}-48} \\
(n=12)\end{array}$ & $\begin{array}{l}b / a_{\mathrm{KPC}}+b a_{\mathrm{VIM}} \\
(n=14)\end{array}$ & $\begin{array}{l}b l a_{\mathrm{NDM}}+b l a_{\mathrm{OXA}-48} \\
(n=2)\end{array}$ & $\begin{array}{l}b l a_{\mathrm{KPC}}+b l a_{\mathrm{OXA}-48} \\
(n=1)\end{array}$ \\
\hline None & $21(7.0)$ & $19(9.5)$ & & & $2(16.7)$ & & & \\
\hline$a a c\left(6^{\prime}\right)-1 b$ & $42(14.0)$ & $24(12.0)$ & $17(34.0)$ & & $1(8.3)$ & & & \\
\hline $\operatorname{aac}\left(6^{\prime}\right)-1 b+\operatorname{ant}\left(3^{\prime}\right)-1$ & $12(4.0)$ & $9(4.5)$ & & $3(14.3)$ & & & & \\
\hline$a a c\left(6^{\prime}\right)-1 b+a p h\left(3^{\prime}\right)-1 a$ & $28(9.3)$ & $27(13.5)$ & & & & $1(7.1)$ & & \\
\hline $\begin{array}{l}a a c\left(6^{\prime}\right)-1 b+a p h\left(3^{\prime}\right)-1 a \\
+\operatorname{ant}\left(3^{\prime}\right)-1\end{array}$ & $86(28.7)$ & $71(35.5)$ & & $4(19.0)$ & & $11(78.6)$ & & \\
\hline $\operatorname{aac}\left(3^{\prime}\right)-11 a$ & $3(1.0)$ & & $2(4.0)$ & & $1(8.3)$ & & & \\
\hline $\operatorname{aac}\left(3^{\prime}\right)-11 a, \operatorname{ant}\left(3^{\prime}\right)-1$ & $2(0.7)$ & & & $2(9.5)$ & & & & \\
\hline $\begin{array}{l}\operatorname{aac}\left(3^{\prime}\right)-\| a, \operatorname{aph}\left(3^{\prime}\right)-1 a, \\
\operatorname{ant}\left(3^{\prime}\right)-1\end{array}$ & $1(0.3)$ & & & & & & $1(*)$ & \\
\hline$a a c\left(6^{\prime}\right)-1 b+a a c\left(3^{\prime}\right)-11 a$ & $32(10.7)$ & $1(0.5)$ & $28(56.0)$ & & $2(16.7)$ & & $1(*)$ & \\
\hline $\begin{array}{l}\operatorname{aac}\left(6^{\prime}\right)-1 b+\operatorname{aac}\left(3^{\prime}\right)-11 a, \\
\operatorname{ant}\left(3^{\prime}\right)-1\end{array}$ & $5(1.7)$ & $1(0.5)$ & & & $4(33.3)$ & & & \\
\hline $\begin{array}{l}a a c\left(6^{\prime}\right)-1 b+a a c\left(3^{\prime}\right)-11 a \\
+a p h\left(3^{\prime}\right)-1 a\end{array}$ & $8(2.7)$ & $5(2.5)$ & $1(2.0)$ & & $2(16.7)$ & & & \\
\hline $\begin{array}{l}\operatorname{aac}\left(6^{\prime}\right)-1 b+\operatorname{aac}\left(3^{\prime}\right)-\| l a \\
+a p h\left(3^{\prime}\right)-1 a, \operatorname{ant}\left(3^{\prime}\right)-1\end{array}$ & $19(6.3)$ & $17(8.5)$ & & $2(9.5)$ & & & & \\
\hline$a p h\left(3^{\prime}\right)-l a$ & $1(0.3)$ & $1(0.5)$ & & & & & & \\
\hline $\operatorname{aph}\left(3^{\prime}\right)-\operatorname{la}, \operatorname{ant}\left(3^{\prime}\right)-1$ & $2(0.7)$ & $2(1.0)$ & & & & & & \\
\hline $\operatorname{ant}\left(3^{\prime}\right)-1$ & $4(1.3)$ & $2(1.0)$ & & $1(4.8)$ & & $1(7.1)$ & & \\
\hline$r m t B+$ any $A M E$ & $22(7.3)$ & $15(7.5)$ & & $6(28.6)$ & & & & $1(*)$ \\
\hline $\begin{array}{l}\operatorname{armA}, \operatorname{aac}\left(6^{\prime}\right)-1 b, \operatorname{aph}\left(3^{\prime}\right)-1 a \\
\operatorname{ant}\left(3^{\prime}\right)-1\end{array}$ & $1(0.3)$ & $1(0.5)$ & & & & & & \\
\hline $\begin{array}{l}\operatorname{aac}\left(6^{\prime}\right)-1 b+\operatorname{ant}\left(2^{\prime}\right)-1 a \\
+\operatorname{ant}\left(3^{\prime}\right)-1\end{array}$ & $1(0.3)$ & & & & & $1(7.1)$ & & \\
\hline $\begin{array}{l}\operatorname{aac}\left(6^{\prime}\right)-1 b+\operatorname{ant}\left(2^{\prime}\right)-1 a \\
+a p h\left(3^{\prime}\right)-1 a\end{array}$ & $1(0.3)$ & $1(0.5)$ & & & & & & \\
\hline$a a c\left(6^{\prime}\right)-l b+a p h\left(3^{\prime}\right)-V I$ & $4(1.3)$ & $3(1.5)$ & $1(2.0)$ & & & & & \\
\hline $\begin{array}{l}a a c\left(6^{\prime}\right)-1 b+a p h\left(3^{\prime}\right)-l a \\
+a p h\left(3^{\prime}\right)-V I\end{array}$ & $1(0.3)$ & $1(0.5)$ & & & & & & \\
\hline $\begin{array}{l}a a c\left(6^{\prime}\right)-1 b+a p h\left(3^{\prime}\right)-V I \\
+\operatorname{ant}\left(3^{\prime}\right)-1\end{array}$ & $1(0.3)$ & & & $1(4.8)$ & & & & \\
\hline $\begin{array}{l}\operatorname{aac}\left(6^{\prime}\right)-\mid b+a a c\left(3^{\prime}\right)-\| l a \\
+a p h\left(3^{\prime}\right)-V I\end{array}$ & $1(0.3)$ & & $1(2.0)$ & & & & & \\
\hline $\begin{array}{l}\operatorname{aac}\left(6^{\prime}\right)-1 b+\operatorname{aac}\left(3^{\prime}\right)-\| l a \\
+\operatorname{ant}\left(3^{\prime}\right)-I+\operatorname{aph}\left(3^{\prime}\right)-\operatorname{la} \\
+\operatorname{aph}\left(3^{\prime}\right)-\mathrm{VI}\end{array}$ & $2(0.7)$ & & & $2(9.5)$ & & & & \\
\hline $\begin{array}{l}\text { aac }\left(6^{\prime}\right)-1 b \pm \text { any other } \\
\text { AME/RMT }\end{array}$ & $254(84.7)$ & $168(84.0)$ & $48(96.0)$ & $15(71.4)$ & $9(75.0)$ & $13(92.9)$ & $1(*)$ & \\
\hline $\begin{array}{l}\left.\text { aac( } 3^{\prime}\right)-\| l a \pm \text { any other } \\
\text { AME/RMT }\end{array}$ & $76(25.3)$ & $26(13.0)$ & $32(64.0)$ & 7 (33.3.0) & $9(75.0)$ & & $2(*)$ & \\
\hline $\begin{array}{l}\text { aph }\left(3^{\prime}\right)-l a \pm \text { any other } \\
\text { AME/RMT }\end{array}$ & $167(55.7)$ & $137(68.5)$ & $1(2.0)$ & $14(66.7)$ & $2(16.7)$ & $12(85.7)$ & $1(*)$ & \\
\hline $\begin{array}{l}\text { ant }\left(3^{\prime}\right)-I \pm \text { any other } \\
\text { AME/RMT }\end{array}$ & $156(52.0)$ & $126(63.0)$ & & $21(100.0)$ & $4(33.3)$ & $13(92.9)$ & $1(*)$ & $1\left(^{*}\right)$ \\
\hline $\begin{array}{l}\text { aph }\left(3^{\prime}\right)-V I \pm \text { any other } \\
\text { AME/RMT }\end{array}$ & $9(3.0)$ & $4(2.0)$ & $2(4.0)$ & $3(14.3)$ & & & & \\
\hline $\begin{array}{l}\text { ant }\left(2^{\prime}\right)-l a \pm \text { any other } \\
\text { AME/RMT }\end{array}$ & $3(1.0)$ & $1(0.5)$ & & $1(4.8)$ & & $1(7.1)$ & & \\
\hline
\end{tabular}




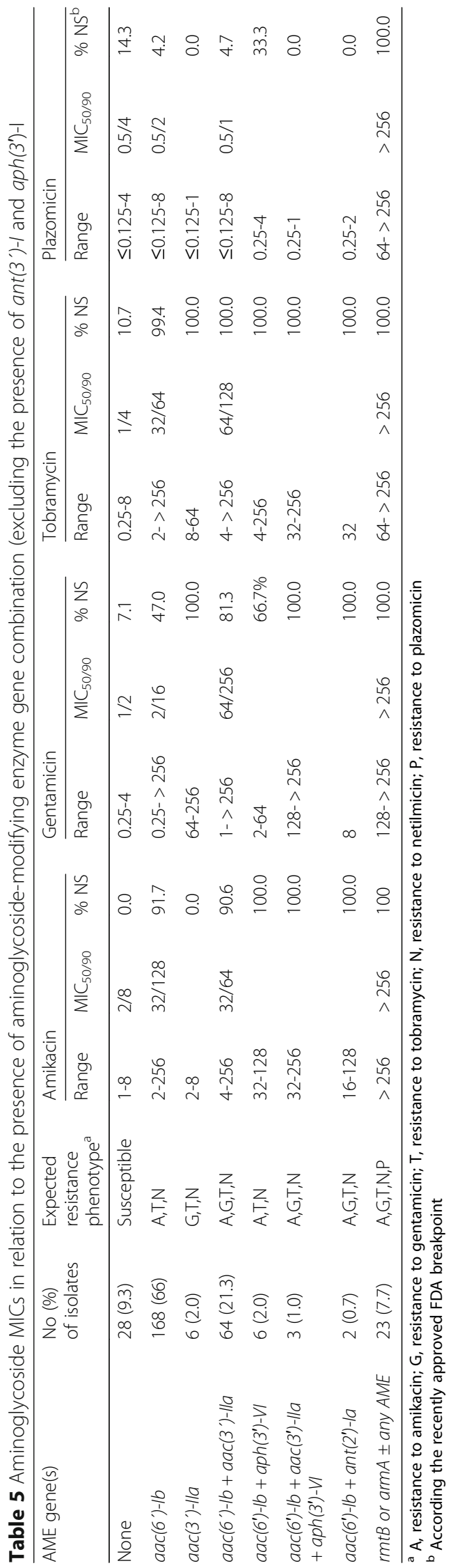



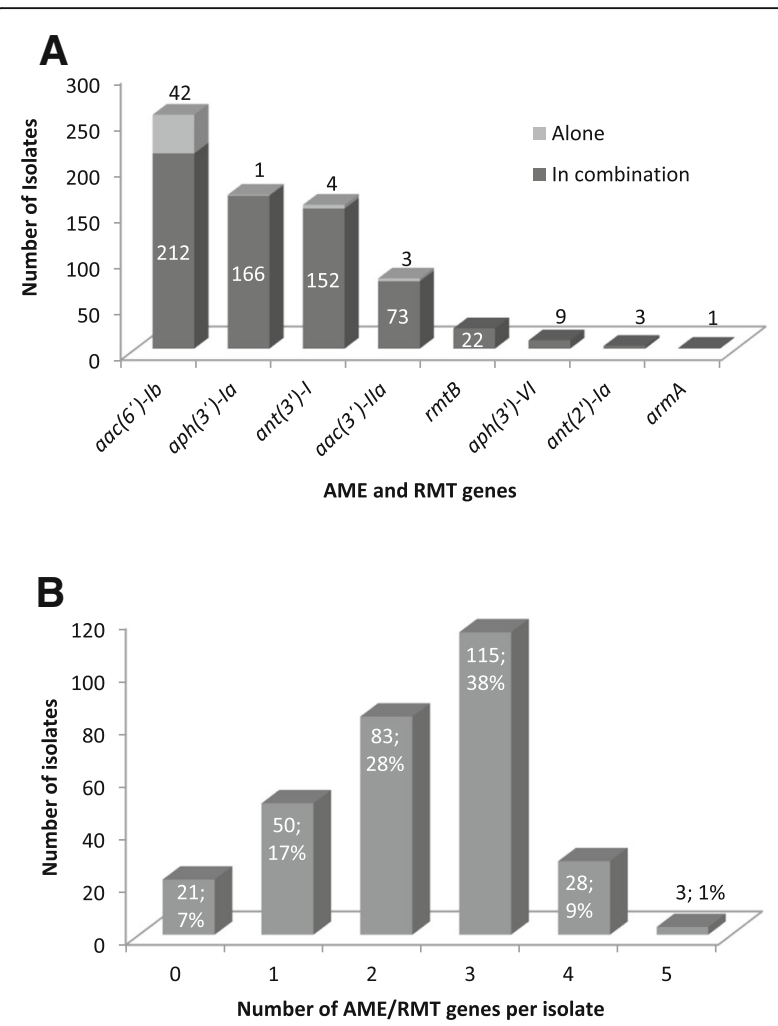

Fig. 1 Aminoglycoside-modifying enzymes (AMEs) and 165 rRNA methylases (RMTs) in carbapenemase-producing K. pneumoniae isolates. a Distribution of AMEs and RMTs. AMEs and RMTs that were present alone and those that were present in combination with other AMEs/RMTs are indicated by gray and black bars, respectively. b Number of AMEs/RMTs possessed by the isolates

due to the presence of AMEs rather than 16S rRNA methyltransferase.

Plazomicin MICs in RMT-negative isolates were consistently lower than those of the other aminoglycosides, and further, the activity of plazomicin was not affected by the number or type of AMEs produced or by the presence of any carbapenemase. As plazomicin was designed to evade modifications conferred by most AMEs [14], these findings are not surprising.

Another noteworthy finding in our study was the apramycin susceptibility. Apramycin is a structurally unique aminoglycoside, a veterinary agent that has not been approved for clinical use, which is likely due to its narrow therapeutic index [15]. It is not inactivated by most of the known AMEs [27], and it is active against producers of the most common N7-G1405 RMTs [15]. Apramycin inhibited $86.7 \%$ of the K. pneumoniae isolates at $\leq 8 \mathrm{mg} / \mathrm{L}$ and it was the second most active drug after plazomicin. This is in accordance with previous evidence that apramycin has broad-spectrum activity against carbapenem-susceptible and carbapenem-resistant Enterobacteriaceae strains from the US, the UK and China [15, 28, 29], suggesting that apramycin may be a candidate for modification to potentially generate new potent aminoglycosides.

\section{Conclusions}

In conclusion, plazomicin was active against most of the contemporary carbapenemase-producing $K$. pneumoniae isolates collected from 14 Greek hospitals, with $87.0 \%$ of the isolates inhibited by an $\mathrm{MIC} \leq 2 \mathrm{mg} / \mathrm{L}$, while $94.2 \%$ of the isolates that did not carry a RMT gene were inhibited by an $\mathrm{MIC} \leq 2 \mathrm{mg} / \mathrm{L}$. Plazomicin demonstrated the most potent in vitro inhibitory activity of all aminoglycosides (regardless of the AMEs produced) and of all other drugs typically used today to treat infections caused by such strains, suggesting that this agent may play an important role for the treatment of MDR K. pneumoniae infections. Dissemination of 16S-RMTases among already MDR organisms is an unwelcome event. Strict infection control measures have to be elaborated to prevent the spread of MDR organisms such as those described here that co-produced carbapenemases and RMTS.

\section{Additional file}

Additional file 1: Table S1. Additional table includes sequences of primers used for simplex and multiplex PCRs for the detection of genes encoding aminoglycoside modifying enzyme and 16S rRNA

methyltransferase genes in K. pneumoniae. (DOCX $19 \mathrm{~kb}$ )

\section{Abbreviations}

AAC: N-acetyltransferase; AME: Aminoglycoside-modifying enzyme; CLSI: Clinical and Laboratory Standards Institute; ESBL: Extended-spectrum $\beta$ lactamase; EUCAST: European Committee on Antimicrobial Susceptibility Testing; EuSCAPE: European Survey on carbapenemase - producing Enterobacteriaceae; KPC: Klebsiella pneumoniae carbapenemase; MDR: Multidrug resistant; MIC: Minimum inhibitor concentration; NARMS: National Antibiotic Resistance Monitoring Study; NCCLS: National Committee for Clinical Laboratory Standards; NDM: New Delhi metallo- $\beta$-lactamase; OXA: Oxacillinase; PCR: Polymerase chain reaction; PDR: Pan drug resistant; PFGE: Pulsed-field gel electrophoresis; QC: Quality control; R: Resistant; RMT: 16S rRNA methyltransferases; S: Susceptible; UPGMA: Unweighted pairgroup method using arithmetic averages; VIM: Verona integron-encoded metallo- $\beta$-lactamase; XDR: Extensively drug resistant

\section{Acknowledgements}

Collaborators of the Study: Sofia Maraki, Viktoria Eirini Mauromanolaki, Department of Clinical Bacteriology, Parasitology, Zoonoses and Geographical Medicine, University Hospital of Heraklion, Heraklion; Vassiliki Papaioannou, Sofia Tsiplakou, Microbiology Department, "KAT" Hospital, Athens; Polyzo Kazila, loanna Diamanti, Cancer Hospital of Thessaloniki "THEAGENEIO", Thessaloniki; Nikoletta Charalampaki, Eleftheria TrikkaGraphakos, Department of Clinical Microbiology "THRIASSIO" General Hospital, Elefsina, Athens; Marina Toutouza, Department of Microbiology Hippokration Athens General Hospital, Athens; Helen Vagiakou, Microbiology Laboratory General Hospital of Athens "G.Gennimatas", Athens; Konstantinos Pappas, Athens Naval Hospital, Athens; Anna Kyratsa, Angeliki Paschali, Microbiology Laboratory General Hospital of Corfu, Corfu; Konstantina Kontopoulou, Department of Microbiology, General Hospital of Thessaloniki "G. Gennimatas", Thessaloniki; Olga Legga, Department of Microbiology, General Hospital of Lamia, Lamia; Efthymia Petinaki, Department of Microbiology, University Hospital of Larissa, Larissa;Helen Papadogeorgaki, Microbiology Laboratory, Hygeia General Hospital, Athens; Efrosini Chinou, Department of Microbiology, St Savvas, Cancer Hospital, Athens. 
The Authors would like to acknowledge the staff from Microbiology Departments of the 14 participating hospitals, for providing the test isolates. Part of these data was presented in 27th European Congress of Clinical Microbiology and Infectious Diseases, 2017, Vienna, Austria (absrt.P0406).

\section{Funding}

Funding for this research was provided by ACHAOGEN INC. (South San Francisco, CA 94080, USA). The funding company did not participate in the study design, data collection, analysis, or interpretation of data, preparation of the manuscript, and the decision to submit the manuscript for publication.

\section{Availability of data and materials}

The datasets are available by request to the corresponding author.

\section{Authors' contributions}

IG and MS designed the research protocol. KN and PA performed all experiments. IG and KN analysed the data and write the manuscript. IG, MS, IK and HG wrote and revised the manuscript. All authors read and approved the final manuscript.

\section{Ethics approval and consent to participate}

The study was approved by the Research Committee of the National and Kapodistrian University of Athens (Research Code Number 70/3/13769).

This research involves no human subjects, human material (tissue), or human data, so no formal ethics approval was required. The clinical isolates were collected as part of routine microbiology laboratory diagnostics, and sent to our research laboratory without any identifiable information of patients.

\section{Consent for publication}

Not applicable.

\section{Competing interests}

IG and MS have received funding for research by Achaogen. Helen Giamarellou has received funding for research by Pfizer. All other authors: none to declare.

\section{Publisher's Note}

Springer Nature remains neutral with regard to jurisdictional claims in published maps and institutional affiliations.

\section{Author details}

${ }^{1}$ Infectious Diseases Laboratory, 4th Department of Internal Medicine, National and Kapodistrian University of Athens, Faculty of Medicine, Athens, Greece. ${ }^{2} 6$ th Department of Internal Medicine, Hygeia Hospital, Athens, Greece. "University General Hospital "ATTIKON", Rimini 1, 12462 Chaidari, Greece.

Received: 30 May 2018 Accepted: 11 February 2019

Published online: 15 February 2019

\section{References}

1. Tzouvelekis LS, Markogiannakis A, Psichogiou M, et al. Carbapenemases in Klebsiella pneumoniae and other Enterobacteriaceae: an evolving crisis of global dimensions. Clin Microbiol Rev. 2012;25(4):682-707. https://doi.org/ 10.1128/CMR.05035-11.

2. Karaiskos I, Giamarellou H. Multidrug-resistant and extensively drug-resistant gram-negative pathogens: current and emerging therapeutic approaches. Expert Opin Pharmacother. 2014;15(10):1351-70. https://doi.org/10.1517/ 14656566.2014.914172.

3. Karampatakis T, Antachopoulos C, losifidis E, Tsakris A, Roilides E. Molecular epidemiology of carbapenem-resistant Klebsiella pneumoniae in Greece. Future Microbiol. 2016;11:809-23. https://doi.org/10.2217/fmb-2016-0042.

4. Grundmann H, Glasner C, Albiger B, Aanensen DM, Tomlinson CT, Andrasević AT, et al. Occurrence of carbapenemase-producing Klebsiella pneumoniae and Escherichia coli in the European survey of carbapenemaseproducing Enterobacteriaceae (EuSCAPE): a prospective, multinational study. Lancet Infect Dis. 2017;17(2):153-63. https://doi.org/10.1016/S14733099(16)30257-2.

5. Galani I, Karaiskos I, Karantani I, Papoutsaki V, Maraki S, Papaioannou V, Kazila P, Tsorlini H, Charalampaki N, Toutouza M, Vagiakou M, Pappas K, Kyratsa A,
Kontopoulou K, Legga O, Petinaki E, Papadogeorgaki H, Chinou E, Souli M, Giamarellou H, On Behalf Of The Study Collaborators. Epidemiology and resistance phenotypes of carbapenemase-producing Klebsiella pneumoniae in Greece, 2014-2016. Euro Surveill. 2018;23(31). https://doi.org/10.2807/ 1560-7917.ES.2018.23.30.1700775.

6. Leggett JE. Aminoglycosides. In: Bennett JE, Dolin R, Blaser MJ, editors. Mandell, Douglas, and Bennett's principles and practice of infectious diseases. Philadelphia: Elsevier Saunders; 2015. p. 224-33.

7. Doi Y, Wachino Jl, Arakawa Y. Aminoglycoside resistance: the emergence of acquired 16S ribosomal RNA methyltransferases. Infect Dis Clin N Am. 2016; 30(2):523-37. https://doi.org/10.1016/j.idc.2016.02.011.

8. Galani I. Plazomicin: Aminoglycoside antibiotic. Drugs Futur. 2014;39(1):2535. https://doi.org/10.1358/dof.2014.39.1.2095267.

9. CLSI. Methods for dilution antimicrobial susceptibility tests for Bacteria that grow aerobically; approved standard —-tenth edition. CLSI document M07A10. Wayne: Clinical and Laboratory Standards Institute; 2015.

10. CLSI. Performance standards for antimicrobial susceptibility testing. 28th ed. CLSI supplement M100. Wayne: Clinical and Laboratory Standards Institute; 2018.

11. NCCLS. Performance standards for antimicrobial disk and dilution susceptibility tests for Bacteria isolated from animals; informational supplement. NCCLS document M31-S1. Wayne: National Committee for Clinical Laboratory Standards; 2004

12. European Society of Clinical Microbiology and Infectious Diseases [Internet]. Clinical breakpoints version 8.0. In European committee on antimicrobial susceptibility testing. Växjö: EUCAST; 2018. Available from: http://www. eucast.org/clinical_breakpoints/

13. Magiorakos AP, Srinivasan A, Carey RB, Carmeli Y, Falagas ME, Giske CG, et al. Multidrug-resistant, extensively drug-resistant and pandrug-resistant bacteria: an international expert proposal for interim standard definitions for acquired resistance. Clin Microbiol Infect Dis. 2012;18(3):268-81. https://doi. org/10.1111/j.1469-0691.2011.03570.x.

14. Aggen JB, Armstrong ES, Goldblum AA, Dozzo P, Linsell MS, Gliedt MJ, Hildebrandt DJ, Feeney LA, Kubo A, Matias RD, Lopez S, Gomez M, Wlasichuk KB, Diokno R, Miller GH, Moser HE. Synthesis and spectrum of the neoglycoside ACHN-490. Antimicrob Agents Chemother. 2010;54(11):463642. https://doi.org/10.1128/AAC.00572-10.

15. Livermore DM, Mushtaq S, Warner M, Zhang JC, Maharjan S, Doumith M, Woodford N. Activity of aminoglycosides, including ACHN-490, against carbapenem-resistant Enterobacteriaceae isolates. J Antimicrob Chemother. 2011;66(1):48-53. https://doi.org/10.1093/jac/dkq408.

16. Almaghrabi R, Clancy CJ, Doi Y, Hao B, Chen L, Shields RK, Press EG, lovine NM, Townsend BM, Wagener MM, Kreiswirth B, Nguyen MH. Carbapenemresistant Klebsiella pneumoniae strains exhibit diversity in aminoglycosidemodifying enzymes, which exert differing effects on plazomicin and other agents. Antimicrob Agents Chemother. 2014;58(8):4443-51. https://doi.org/ 10.1128/AAC.00099-14

17. Haidar G, Alkroud A, Cheng S, Churilla TM, Churilla BM, Shields RK, Doi Y, Clancy CJ, Nguyen MH. Association between the presence of aminoglycoside-modifying enzymes and in vitro activity of gentamicin, tobramycin, amikacin, and plazomicin against Klebsiella pneumoniae carbapenemase-and extended-spectrum- $\beta$-lactamase-producing Enterobacter species. Antimicrob Agents Chemother. 2016;60(9):5208-14. https://doi.org/10.1128/AAC.00869-16.

18. Zhang Y, Kashikar A, Bush K. In vitro activity of plazomicin against $\beta$ lactamase-producing carbapenem-resistant Enterobacteriaceae (CRE). J Antimicrob Chemother. 2017;72(10):2792-5. https://doi.org/10.1093/jac/ $\mathrm{dk} \times 261$.

19. Martins AF, Bail L, Ito CAS, da Silva Nogueira K, Dalmolin TV, Martins AS, Rocha JLL, Serio AW, Tuon FF. Antimicrobial activity of plazomicin against Enterobacteriaceae-producing carbapenemases from 50 Brazilian medical centers. Diagn Microbiol Infect Dis. 2018;90(3):228-32. https://doi.org/10. 1016/j.diagmicrobio.2017.11.004.

20. Haldorsen BC, Simonsen GS, Sundsfjord A, Samuelsen O, Norwegian Study Group on Aminoglycoside Resistance. Increased prevalence of aminoglycoside resistance in clinical isolates of Escherichia coli and Klebsiella spp. in Norway is associated with the acquisition of AAC(3)-II and AAC(6)-Ib. Diagn Microbiol Infect Dis. 2014;78(1):66-9. https://doi.org/10.1016/j. diagmicrobio.2013.10.001.

21. López-Diaz MD, Culebras E, Rodríguez-Avial I, Rios E, Viñuela-Prieto JM, Picazo JJ, Rodríguez-Avial C. Plazomicin activity against 346 extended- 
Spectrum- $\beta$-lactamase/AmpC-producing Escherichia coli urinary isolates in relation to aminoglycoside-modifying enzymes. Antimicrob Agents Chemother. 2017;61(2). https://doi.org/10.1128/AAC.02454-16.

22. Ramirez MS, Nikolaidis N, Tolmasky ME. Rise and dissemination of aminoglycoside resistance: the aac $\left(6^{\prime}\right)-16$ paradigm. Front Microbiol. 2013;4: 121. https://doi.org/10.3389/fmicb.2013.00121

23. Giakkoupi P, Tryfinopoulou K, Kontopidou F, Tsonou P, Golegou T, Souki H, Tzouvelekis L, Miriagou V, Vatopoulos A. Emergence of NDM-producing Klebsiella pneumoniae in Greece. Diagn Microbiol Infect Dis. 2013;77(4):3824. https://doi.org/10.1016/j.diagmicrobio.2013.09.001.

24. Voulgari E, Gartzonika C, Vrioni G, Politi L, Priavali E, Levidiotou-Stefanou S, Tsakris A. The Balkan region: NDM-1-producing Klebsiella pneumoniae ST11 clonal strain causing outbreaks in Greece. J Antimicrob Chemother. 2014; 69(8):2091-7. https://doi.org/10.1093/jac/dku105.

25. Campos JC, da Silva MJ, dos Santos PR, Barros EM, Pereira Mde O, Seco BM, Magagnin CM, Leiroz LK, de Oliveira TG, de Faria-Júnior C, Cerdeira LT, Barth AL, Sampaio SC, Zavascki AP, Poirel L, Sampaio JL. Characterization of Tn3000, a transposon responsible for b/a NDM-1 $_{1}$ dissemination among Enterobacteriaceae in Brazil, Nepal, Morocco, and India. Antimicrob Agents Chemother. 2015;59(12):7387-95. https://doi.org/10.1128/AAC.01458-15 .

26. Papagiannitsis CC, Malli E, Florou Z, Sarrou S, Hrabak J, Mantzarlis K, Zakynthinos E, Petinaki E. Emergence of sequence type 11 Klebsiella pneumoniae coproducing NDM-1 and VIM-1 metallo- $\beta$-lactamases in a Greek hospital. Diagn Microbiol Infect Dis. 2017;87(3):295-7. https://doi.org/ 10.1016/j.diagmicrobio.2016.12.008.

27. Ramirez MS, Tolmasky ME. Aminoglycoside modifying enzymes. Drug Resist Updat. 2010;13(6):151-71. https://doi.org/10.1016/j.drup.2010.08.003.

28. Smith KP, Kirby JE. Evaluation of apramycin activity against carbapenemresistant and -susceptible strains of Enterobacteriaceae. Diagn Microbiol Infect Dis. 2016;86(4):439-41. https://doi.org/10.1016/.jdiagmicrobio.2016.09.002.

29. Hu Y, Liu L, Zhang X, Feng Y, Zong Z. In Vitro activity of neomycin, streptomycin, Paromomycin and Apramycin against Carbapenem-resistant Enterobacteriaceae clinical strains. Front Microbiol. 2017;8:2275. https://doi. org/10.3389/fmicb.2017.02275.

Ready to submit your research? Choose BMC and benefit from:

- fast, convenient online submission

- thorough peer review by experienced researchers in your field

- rapid publication on acceptance

- support for research data, including large and complex data types

- gold Open Access which fosters wider collaboration and increased citations

- maximum visibility for your research: over $100 \mathrm{M}$ website views per year

At $\mathrm{BMC}$, research is always in progress.

Learn more biomedcentral.com/submissions 